\title{
TEACHING-SERVICE PARTNERSHIP IN THE UNIFIED HEALTH SYSTEM: IMPLEMENTATION OF OUTPATIENT
HARMACOTHERAPEUTICAL FOLLOW-UP IMPLEMENTATION OF OUTPATIENT
PHARMACOTHERAPEUTICAL FOLLOW-UP
}

\section{ABSTRACT}

Background: The irrational medicine use is a public health problem and, in this context, the pharmacist assists in improving the use of drugs, reducing the risks of morbidity and mortality and the costs of pharmacotherapy. Data referring to the pharmacy service highlight the importance and the emerging need of insertion of this professional in the health teams. Objective: To describe the process of implementation of the Pharmacotherapeutical follow-up Service in a Multidisciplinary University Outpatient Unit (UOU) and the variables related to the evaluation of the structure and the process. Methods: It is an experience report with all the steps of an implantion process. The data were collected through our own forms through the Integrated Health System (SIS - "SistemaIntegrado de Saúde", in Portuguese Language) and the pharmacy follow-up records registered between November 2015 and November 2016. Results: In the 12 months of the implementation, 312 consultations were carried out, with the majority of the patients $(67 \%)$ arriving at the service by referrals from the doctors who work in the UOU, followed by referrals for primary care (22\%). Conclusions: The service was implemented with an adequate structure to the pharmaceutical follow-up process, and the teaching-service integration was important for its operation. Difficulties of recognition of the service by the population and by other health units of the municipality cause the referral flow to be below than the capacity of service attendance.

Keywords: Clinical pharmacy,health service, pharmaceutical care.

\section{INTRODUCTION}

The irrational use of medicines is a public health problem and, in this context, the pharmaceutical professional incorporated into health teams has a great potential in improving the use of medicines, reducing the risks of morbidity and mortality and the costs of pharmacotherapy. In Salto Grande - SP, the implementation of a clinical pharmacy service was associated to the greater effectiveness of the treatment, since all the clinical parameters evaluated improved significantly among the patients served by the service. ${ }^{2}$ Other studies have also showed improvements in glycemic control, LDL-c levels,as well as in the resolution of pharmacotherapeutical problems after the implementation of the service. ${ }^{3-4}$

The effectiveness scenario of the clinical pharmacy services corroborates the emerging need of insertion of the pharmacist in the health teams, as well as the reformulation of the professional training profile of the pharmacist, ${ }^{5,6}$ in addition to the gains it brings to the community, which benefits from the university-health services interaction, since it provides quality care with scientific rigor. ${ }^{7}$

In this context, the present study aimed at describing the experience of a process of implementation of a Pharmacotherapeutical followup service, implemented through a university-service partnership.

\section{METHODOLOGY}

\section{Study Design}

This is an experience report, which provides for the implementation of a Pharmacotherapeutical follow-up service that happened in stages and through a partnership between a university (UFSJ$\mathrm{CCO}$ ) and the health service in the municipality of Divinópolis-MG (SEMUSA).

\section{Clinical service implementation}

The implementation of the Pharmacotherapeutical follow-up occurred in stages, which are: negotiations between university and health service; availability and selection of the clinical pharmacist; training for clinical practice; organization and standardization of the materials to be used; and establishment of the care flow. In this report, the structure and process variables of the implemented service will also be analyzed.

\section{Context}

The study was conducted at the University Outpatient Unit (UOU) in the city of Divinópolis, Minas Gerais, Brazil. This outpatient unit was implemented in 2015 to meet the community's care demands and the university's academic demands.

\section{Universidade Federal de São João Del-Rei \\ 2 Secretaria Municipal de Saúde de Divinópolis - MG}

Received: 29/12/2016

Revised: 07/02/2018

Accpted: 27/02/2018

How to cite this article: Tinoco Ms, Nogueira LD, Pereira ML, Figueiredo RC, Faria AG, Enes TB, Sanches C, Fernandes MR, Abreu DGA e Baldoni AO. Teaching-Service Partnership in the Unified Health System: Implementation of Outpatient

Pharmacotherapeutical FollowUp. Rev. Bras. Farm. Hosp. Serv. Saúde, 9(1): 1-4, 2018.

DOI: $10.30968 /$ rbfhss.2018.091.003

Corresponding author: André Oliveira Baldoni Universidade Federal de São João

Del-Rei

R. Sebastião Gonçalves Coelho, 400 - Sala 306.1C - Chanadour, Divinópolis. CEP: 35501-296. MG

- Brasil. andrebaldoni@ufsj.edu.br 
For the implementation at the lowest possible cost, restructuring and reallocation by both institutions was necessary, thus, the service provided the physical space and the university provided the furniture and instruments for its operation, such as tables, chairs, cabinets, and materials for clinical care. In addition, the internships and practical classes were tailored to the needs of the service. In the outpatient unit there are human resources of both institutions, being of the area of Nursing, Pharmacy and Medicine.

The pharmaceutical service of the municipality has 13 active pharmacists in the Medication management cycle $^{8}$ and two clinical pharmacy services: one in a family health unit ${ }^{9}$ and another at the secondary care outpatient unit, which will be presented in this study.

\section{Data collection and analysis}

The data collection was carried out through our own form, a pharmacy follow-up form, and through the municipal computerized electronic health system (SIS). All the data were analyzed in Epilnfo ${ }^{\mathrm{TM}}$, version 7.1.5.0. Descriptive analyzes were performed with frequency, distribution and generation of graphs.

\section{Ethical aspects}

The work was approved by the Research Ethics Committee of UFSJ (CAAE: 58510716.8.0000.5545).

\section{RESULTS AND DISCUSSION}

\section{Service Implementation Stages}

\section{Negotiations between SEMUSA and UFSJ/CCO}

In 2015, when the UOU began its activities offering care by teachers and students of the courses of Medicine and Nursing, the management of the Pharmaceutical Services at SEMUSA in Divinópolis (MG) proposed, in partnership with professors of the Pharmacy Course of UFSJ/CCO, the implementation of a Clinical Pharmacy service at the UOU. After some resistance by some managers of the municipality, due to lack of knowledge about the service and its potential, the project was approved by SEMUSA and the implementation process began.

\section{Availability and selection of the clinical pharmacist}

As a counterpart from SEMUSA, an effective professional was available to work in the service. And, due to the need of a clinical profile, a selective process was conducted by UFSJ and SEMUSA, based on the evaluation of the candidates' technical knowledge.

\section{Training for the clinical practice}

The training was carried out by professors from the clinical pharmacy area of UFSJ/CCO, and it was offered to the selected pharmacist, to other pharmacists from the public health network, and to the students of the Clinical Pharmacy Academic League (LaFarC-UFSJ).

In the training, an active teaching methodology was used and the following topics were addressed:

- Historical and conceptual aspects on pharmaceutical care;

- Health based on evidence and sources of health information;

- Management of pharmacotherapy in:

- Diabetes Mellitus (DM);

- Arterial Hypertension (AH);

- Asthma;

- Osteoporosis and Chronic Kidney Disease (CKD);
- Heart Failure (HF);

- Heart diseases.

For the training, problem-based learning was used, with cases elaborated from patients' data from the city, obtained from the SIS, in order to improve the skills and abilities necessary for the clinical practice.

For the students' qualification, the supervised practice was also used to establish theoretical-practical relations.

\section{Organization and standardization of materials to be used}

The clinical pharmacist, together with professors and students of the UFSJ Pharmacy course, prepared the pharmaceutical care form based on "Pharmaceutical Care Practice: The Clinician's Guide"10 and on "Método Clínico de Atenção Farmacêutica” (Clinical Method of Pharmaceutical Care). ${ }^{11}$ Publicity posters, overdue drug collectors, health education materials and a clinical pharmacy guide were also prepared to support the work of the pharmacist and the students working on the service, and it acts as a quick reference source (materials available for access on https://ufsj. edu.br/lafarc).

\section{Establishment of the care flow}

Access to the service happens through primary care (scheduled by the SIS); by active search of the pharmacist (scheduled by the pharmacist); by referral of the UOU doctors (referring directly to the pharmacist); and by spontaneous demand (according to the availability of the pharmacist).

\section{Structure Variables}

The clinical pharmacy service has an exclusive-use office (Figure 1), 18 multi-user offices (accessed if necessary) and a classroom for study. The exclusive office has two computers with access to the SIS and the Internet, two desks, two cabinets, two message boards, an anthropometric scale and other devices and supplies required for routine work.

Figure 1.Office for exclusive use of the Pharmaceutical Care in Divinópolis-MG (2016).

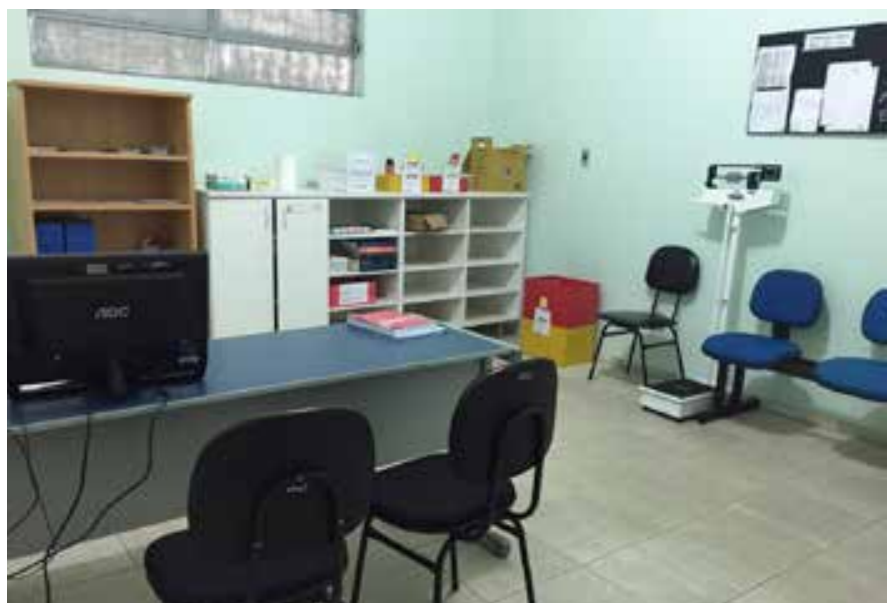

\section{Human Resources}

In addition to the clinical pharmacist, there are four professors from the Pharmacy course of UFSJ/CCO (two in the patient care and supervision of the students, one in the service management and another in the evaluation of the results) and 51 students (undergraduates, masters, extension students, and members of LaFarC-UFSJ), being characterized as a school service and contributing in an important way to the training of students. 


\section{Process Variables}

The monthly number of appointments is shown in figure 2. It should be highlighted that in July there was no attendance due to the absence of the school term,

Figure 2. Monthly amount of consultations, new consultations and returns of the Clinical Pharmacy Service, from November 2015 to November 2016, in Divinópolis-MG.

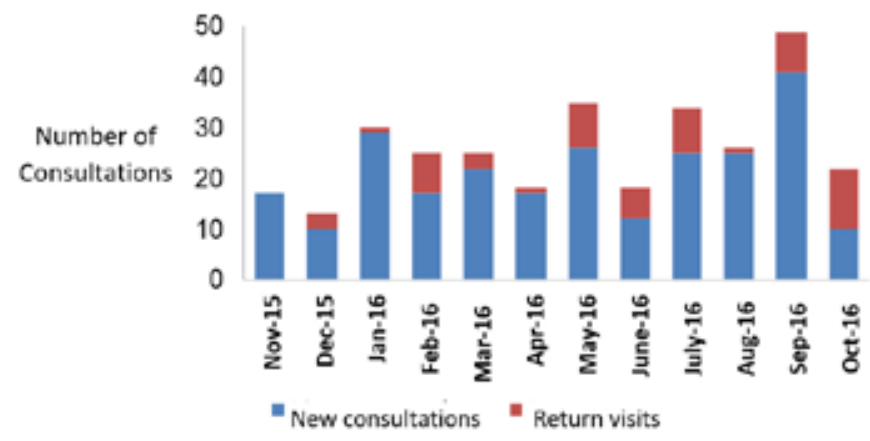

The majority of the patients (67\%) arrived at the clinical pharmacy service through referrals from the UOU doctors (suggesting a closer medical-pharmaceutical relationship), followed by patients referred by primary care $(22 \%)$. In addition, there are patients who spontaneously sought the service, through active search and from the Polyclinic.

The results related to the origin of the patients point to the need for greater recognition of the service by primary care professionals and, therefore, the participation of the pharmacist in the dissemination of the new service with these teams is fundamental. To increase referrals, a new strategy has been used: the active search by patients, through defined criteria. ${ }^{12}$ However, it is known that the most effective strategy for consolidating the service will be the generation of clinical, humanistic and economic results.

Regarding the challenges and perspectives, the implementation of the service was possible due to a joint effort of different actors and by the enhanced partnership academy-health service. It is believed that the process has been successful, despite the challenges, including some intrinsic to the public health service. The documentary available in the following link qualitatively explains some results and advances obtained with the implementation of the service: https://www.youtube.com/ watch? $\mathrm{v}=\mathrm{LHIGqmDJOs} 8 \& \mathrm{t}=2 \mathrm{~s}$.

In view of these results and potentialities, it is important to highlight that the academy-service integration brings bi-directional benefits to teaching and to the health service..$^{13}$ As already described in the literature, in practice, it is possible to observe that the presence of future professionals among the professionals already inserted in the network causes the students to develop a critical view on health and understand the importance of public policies. In addition, the presence of students in the service serves as a stimulus so that professionals are always improving and qualifying. ${ }^{14,15}$

This experience has been successful and it is believed that the main potential for this success is the partnership that provides bilateral results, and the decisions have been taken in a collegial and harmonious way, involving the service and the university. Regarding the weaknesses of the service, it is believed that the lack of knowledge of the population and health professionals about the clinical pharmacy service is a barrier that still needs to be overcome, by means of clinical, humanistic and economic results, and also by means of its dissemination to primary health care teams.

\section{CONCLUSIONS}

Although recent, the implementation of the clinical pharmacy service benefited different actors involved in this process. Initially, through the provision of a quality service, users were able to have better knowledge of the process of using their medicines, which may contribute to better results of their pharmacotherapy. The health professionals had the opportunity to count on the support of another service for the care of the patient. Students had the opportunity to develop knowledge, skills and attitudes for the clinical practice in a broader perspective, as well as having the experience of working in the pharmaceutical service. Teachers had the opportunity to strengthen their role as educators, and also to learn something new from the exposure to the typical challenges.

\section{Financial Source}

Pro-Rectory of Extension and Community Affairs of the Federal University of São João Del-Rei (UFSJ).

\section{Conflict Of Interests}

The authors declare that they do not have any type of conflict of interest.

\section{Authors' Contributions}

MST, LDN, MRF and DGAA: data collection, scientific article writing, analysis and discussion of the results, approval of the final version. MLP, RCF, CS and AOB: Creation of a proposal, articulation with the institutions involved, analysis and interpretation of results, critical review of content, approval of the final version. AGF, TBE: approval of the proposal, articulation with the institutions involved, data collection, analysis and interpretation of results, critical review of content, approval of the final version. All authors are responsible for all aspects of the work to ensure accuracy and any part of the work.

\section{Acknowledgments}

A municipal health department of Divinópolis-MG (SEMUSA).

\section{REFERENCES}

1. Vieira, FS. Possibilidades de contribuição do farmacêutico para a promoção da saúde. Ciênc. saúde coletiva, Rio de Janeiro , 2007, 12(1):213-220. Disponível em: <http://www.scielosp.org/scielo. php?script=sci_arttext\&pid=S1413-81232007000100024\&lng=en \&nrm=iso> Acesso em: 12 de novembro de 2016.

2. Obreli-neto PR, Marusic S, Guidoni CM, et al. Economic evaluation of a pharmaceutical care program for elderly diabetic and hypertensive patients in primary healthcare: a 36-month randomized, controlled clinical trial. Journal of Managed Care \& Specialty Pharmacy, 2015, 21(1): 66-75

3. Kiel PJ; Mccord AD. Pharmacist impact on clinical outcomes in a diabetes disease management program via collaborative practice.Ann. Pharmacother., 2005, 39(11):1828-1832.

4. Strand LM, Cipolle RJ, Morley PC, et al. The impact of pharmaceutical care practice on the practitioner and the patient in the ambulatory practice setting: twenty five years of experience.Curr. Pharm. Des., 2004, 10(31):3987-4001.

5. BRASIL. Ministério da Educação. Resolução no 6, de 19 de Outubro de 2017. Institui as Diretrizes Curriculares Nacionais do Curso de Graduação em Farmácia e dá outras providências. Diário Oficial da União, Brasília, 20 de outubro de 2017, Seção 1, p. 30. Disponível em: <http://portal.mec.gov.br/index.php?option=com docman \&view =download \&alias $=74371$-rces $006-17$ pdf\&category_slug=outubro-2017-pdf\&Itemid=30192>. Acesso em 01 de fevereiro de 2018.

6. LIMA, D. P. et al. A importância da integração universidade e serviços de saúde. Rev. Ciênc. Ext. v.6, n.1, p.137, 2010. 
7. Ellery AEL, Bossi MLM, Loiola FA. Integração Ensino, Pesquisa e Serviços em Saúde: antecedentes, estratégias e iniciativas. Saúde Soc. São Paulo, v.22, n.1, p.187-198, 2013.

8. DIVINÓPOLIS. Secretaria Municipal de Saúde. Plano Municipal de Saúde 2009/2012. Aprovado pelo CMS em reunião ordinária realizada em 29/10/2009

9. Meireles BL, Grossi EB, Gonçalves PJ, et al. Implantação de serviços clínicos farmacêuticos em uma unidade da Estratégia Saúde da Família: uma parceria entre universidade e Secretaria de Saúde. Experiências exitosas de farmacêuticos no SUS, 2015, 3(3): 36-43.

10. Cipolle RJ, Strand LM, Morley PC. Pharmaceutical Care Practice: The Clinician's Guide. 2nd ed. New York: McGraw-Hill, 2004, 624p.

11. Correr CJ, Otuki MF. Método Clínico de Atenção Farmacêutica. Março, 2011. Disponível em:<http://www.saude.sp.gov.br/ resources/ipgg/assistencia-farmaceutica/otuki-metodoclinicoparaa tencaofarmaceutica.pdf> Acesso em: 23 de novembro de 2016.

12. BRASIL. Conselho Federal de Farmácia. Consulta pública 02/2014 Serviços farmacêuticos: Contextualização e arcabouço conceitual. Disponível em www.cff.org.br. Acessado em 16 de abril de 2015.

13. Lima D, Garbin C, Saliba $\mathrm{N}$, et al. A importância da integração Universidade e serviços de saúde. Revista Ciência em Extensão, 2010, 6(1): 129-137.

14. Brandao ERM, Rocha SV, Silva SS. Práticas de integração ensinoserviço-comunidade: Reorientando a formação médica. Rio de Janeiro, Revista Brasileira de Educação Médica, 2013, 37(4): 573577. Disponível em: <http://www.scielo.br/scielo.php?script=sci arttext\&pid=S0100-55022013000400013\&lng=en\&nrm=iso $>$. Acesso em 06 de Fevereiro de 2018.

15. Pizzinato A, Gustavo AS, Santos BRL, et al . A integração ensinoserviço como estratégia na formação profissional para o SUS. Rio de Janeiro, Revista Brasileira de Educação Médica, 2012, 36(1): 170177. Disponível em: <http://www.scielo.br/scielo.php?script=sci arttext\&pid=S0100-55022012000300025\&lng=en\&nrm=iso $>$. Acesso em 06 de Fevereiro de 2018. 